\title{
SPECIAL ISSUE 60 YEARS OF RAE: FROM A SOLITARY STAR IN THE PAST TO FUTURE CHALLENGES
}

\author{
Especial 60 anos da RAE: De estrela solitária no passado aos desafios futuros \\ Especial 60 años de RAE: De estrella solitaria en el pasado a los desafíos futuros
}

Maria José Tonelli1 ${ }^{1}$ maria.jose.tonelli@fgv.br | ORCID: 00oo-0002-6585-1493

Felipe Zambaldi ${ }^{1}$ | felipe.zambaldi@fgv.br | ORCID: 00o0-0002-5378-6444

${ }^{1}$ Fundação Getulio Vargas, Escola de Administração de Empresas de São Paulo, São Paulo, SP, Brazil

\begin{abstract}
The text presents the invited articles of this special edition of $R A E$ to commemorate its 6oth anniversary. Besides that, it aims at reflecting on the past, the present and the future of this and of other Brazilian scientific journals in Administration. It starts by presenting the historical role of the journal in constructing the Brazilian academia in Administration and its impact on several generations of researchers in the country. The main problems faced by RAE are then addressed, as are its future challenges, which may, possibly, be useful for other Brazilian journals in the field. The conclusion is that the reduction in inequality between Brazilian and international journals can be seen as a goal for RAE and other Brazilian journals that can now take advantage of favorable winds, such as the United Nations's (UN) Sustainable Development Goals, the Declaration on Research Assessment (DORA) movement, and the potential that accrediting associations have for evaluating the social impact of institutions and their programs. But relying on these favorable winds to do the job alone would be an illusion; there is a lot of a long-term work ahead.
\end{abstract}

KEYWORDS | RAE, the history of Administration in Brazil, Brazilian Administration journals, indexers, challenges.

\section{RESUMO}

Este texto apresenta os artigos convidados para esta edição especial de comemoração dos 60 anos da Revista, com o objetivo de refletir sobre o passado, o presente e o futuro da RAE e das revistas científicas brasileiras em Administração. Apresenta-se, em primeiro lugar, o papel histórico da Revista na construção da academia brasileira em Administração, bem como seu impacto em várias gerações de pesquisadoras e pesquisadores no País. Num segundo momento, são abordados os principais problemas enfrentados na RAE e seus desafios futuros que podem, eventualmente, ser úteis para os demais periódicos brasileiros no campo da Administração. Conclui-se que a redução das desigualdades entre os periódicos nacionais e internacionais pode ser encampada como uma bandeira da RAE e de periódicos brasileiros, valendo-se de ventos favoráveis como os Objetivos de Desenvolvimento Sustentável da Organização das Nações Unidas (ONU), o movimento Declaration on Research Assessment (DORA) e a potencialidade de avaliação do impacto social das instituições e seus programas por parte de entidades acreditadoras. Mas contar com que esses ventos favoráveis, façam o trabalho sozinhos seria uma ilusão; há um longo trabalho pela frente.

PALAVRAS-CHAVE I RAE, história da Administração no Brasil, periódicos brasileiros em Administração, indexadores, desafios.

\section{RESUMEN}

Este texto presenta los artículos invitados a esta edición especial de conmemoración del 60 aniversario de la revista, con el objetivo de reflexionar sobre el pasado, presente y futuro de la RAE y de las revistas científicas brasileñas de Administración. En primer lugar, se presenta el papel histórico de la revista en la construcción de la academia brasileña de Administración, así como su impacto en varias generaciones de investigadores del país. En un segundo momento, se abordan los principales problemas que enfrenta la RAE y sus desafíos futuros que, eventualmente, pueden ser de utilidad para los demás periódicos brasileños del campo de la Administración. Se concluye que la reducción de las desigualdades entre las revistas nacionales e internacionales puede verse como una bandera de la RAE y de las revistas brasileñas, aprovechando vientos favorables como los Objetivos de Desarrollo Sostenible de la Naciones Unidas (ONU), el movimiento Declaration on Research Assessment (DORA) y el potencial de evaluación del impacto social de las instituciones y sus programas por las entidades acreditadoras. Pero contar con que estos vientos favorables hagan el trabajo solos sería una ilusión; por lo tanto, queda un largo trabajo por delante.

PALABRAS CLAVE I RAE, historia de la Administración en Brasil, periódicos brasileños en Administración, indexadores, desafíos. 


\section{INTRODUCTION}

RAE-Revista de Administração de Empresas celebrates its 6oth anniversary in 2021, a year in which the pandemic is provoking all kinds of reflections. This is a difficult year for Brazil*, but also a fertile field for memories and for reflecting on the past and future of Brazilian scientific journals in Administration. As part of the Global South, RAE has anticipated trends, created scientific fields in Administration in the country, such as marketing (Tonelli, 2018), and created a space of resistance, dialogue and interaction. RAE's journey, has been marked by its pioneering spirit, critical approaches and reflections on social issues in Brazil (Bertero, 2011, 2021). It has also been a protagonist in education and research in various areas of Administration and takes part in the "DNA" of many relevant researchers in the field (Paula, 2021). But just as the Brazilian society has been aging, RAE has reached its 6 oth $^{\mathrm{h}}$ year with the challenge of reinventing itself.

This text presents the invited articles of this special edition commemorating the 6oth anniversary of the journal, reflecting on the past, the present and the future of $R A E$ and of the Brazilian scientific journals in Administration. RAE is the longest-running academic journal in Business Administration in Brazil, if we consider that it has been published uninterruptedly since its launch. The authors who were invited to contribute to this edition are part of this history and each one, in their own way, has creatively dealt with the importance of the journal in the academic field of Administration in the country.

By introducing the authors and their invited articles, we reflect first on the historical role of this journal in constructing the Brazilian academia in Administration and on its impact on several generations of researchers in the country. We then address the main problems faced by RAE and its future challenges, which may, eventually, be useful for other Brazilian journals in the field. In the second section, we discuss the issue of the internationalization of journals, a topic that is still very prevalent. We point out that Brazilian journals are suffering from the internationalization objectives of graduate programs that encourage their researchers to publish in international journals with high impact factors. While on the one hand, the internationalization of scientific production allows Brazilian researchers to find a place in the Global North, on the other, this leads them to lose interest in being published in Brazilian journals. The future of our national journals is in jeopardy, given the contradictory demands that researchers and graduate programs must face: to contribute with their solutions for urgent local problems; or to become part of the international community. In this sense, journals need to position themselves, given the growing demand for research that meets the UN's Sustainable Development Goals (2021), and new demands coming from Brazilian regulatory bodies and foreign accreditation agencies that are now seeking to evaluate business schools based on their local social impact (EFMD Global services/Business School Impact System, 2020).

\section{THE INVITED ARTICLES}

The history of RAE reflects the history of teaching and research in Business Administration in Brazil, which has been registered in several manuscripts by Carlos Osmar Bertero commented below. As Editor-in-chief of RAE on two occasions, and a prodigious and successful author with more than 30 articles published in the journal, Carlos Osmar Bertero was also a contributor to several commemorative editions of RAE. In the editorial on the occasion of its 45th anniversary, Bertero (2006a, p.5) dealt with the lack of citizenship in the country, "the historically 
constructed result of a weak civil society, whose burden extends to the most diverse spaces of national life, which was the opposite of academic democracy, in which everyone is considered equally". Bertero (2006a, p.5) continued: "The peer review system is a demonstration of the humbleness by which every author submits her or his production to be judged by colleagues and is obliged to accept it." There is nothing more up-to-date in the contemporary scene: the need for citizenship, the consideration for the efforts of a community to produce knowledge that is supported by the democracy of scientific research, and the pressing need for humbleness in all aspects of social life. In that same edition, Bertero (2006b, p.2) dealt with the role of the Journal on the national scene, as being that of "boldness": "It was intended to have a periodical that would spread a new field in education, whose undergraduate courses had just opened ...". It was in this context that RAE created and dissiminated the development of all areas of Administration in the country, such as Operations, Marketing, Organizations and Organizational Behavior (Tonelli, 2018).

The emphasis on scientific journals began in the 1970s, and the creation of the National Association of Graduate Studies in Administration (Associação Nacional de Pós Graduação e Pesquisa em Administração [ANPAD]) in 1976 played a significant role in such a change of direction (Fachin, 2006). During this period, the country was facing repression by the military government, and journals in the Social Sciences area, in particular, were victims of censorship. During this period, RAE accepted contributions from this field, even though it received countless warnings not to publish topics that criticized the government's economic policy, especially the issue of income distribution. But despite these restrictions, several critical articles were published. They can be considered actions of resistance and the "reaffirmation of a belief in freedom of expression, which is indispensable to scientific production ...", says Bertero (2006b, p. 3). RAUSP-Management Journal also suffered the consequences of that period, and its publication was interrupted (Tonelli, 2017). The acceptance and publication of critical articles in RAE (as well as by São Paulo School of Business Administration - Escola de Administração de Empresas de São Paulo, EAESP - itself) should undoubtedly be further researched.

At the end of the 1970s, with the expansion of scientific production, the journal incorporated the doubleblind evaluation system and, step by step, became established as an academic journal. But there were still few scientific journals, and on the occasion of the Journal's 5oth anniversary, a new article by Bertero (2011) showed that RAE had been a solitary star, shining for decades on the Brazilian stage of academic publications in Administration. In this article, Bertero (2011) dealt with the Journal's origin as a generalist outlet, and proposed that RAE should become a Management journal, an identity it has so far not assumed. This theme has again been taken up by Bertero (2021) in this special edition in his article: "Sixty years of RAE: A journey of criticism, resistance and reinvention", when the author emphasized that although RAE has been a generalist journal since its origin because its editorial body was diverse (Valente \& Serafim, 2006), it stands out for publishing articles in the areas of "Organization and Organization Studies, Strategy and Human Resources - or People - Management". Over the years, it also presented a "... growing methodological sophistication ... unlike the early years when it was a journal that we could consider to be provincial”, says Bertero $(2021$, p. 1) in this edition. But he is optimistic: "There's no doubt that we've moved ahead."

Carlos Osmar Bertero is one of the most accessed authors in RAE, especially his article "The evolution of organizational analysis in Brazil (1961-1993)", in partnership with Tania Margarete Mezzomo Keinert (1994), the classic "The evolution of organizational analysis in Brasil"; "Some observations on the work of G. Elton Mayo" (1968); and "Brazilian scientific production in administration in the 2000s" (2013), in partnership with Flávio 
Carvalho de Vasconcelos, Marcelo Pereira Binder and Thomaz Wood Jr. But his most accessed article, written in partnership with Rafael Alcadipani, deals with the "Cold War and the teaching of management in Brazil: the case of FGV-EAESP" (Alcadipani \& Bertero, 2012). In this article, the authors analyze the spread of North American thought in the post-war period and the North American management model in the country. But here there is a caveat: if, on the one hand, RAE - as a part of the FGV EAESP - had a role in spreading the ideas of American thought in Administration (Alcadipani \& Bertero, 2012; Tonelli, 2018), on the other, the articles by Carlos Osmar Bertero revisited here show that, in a pioneering trend, the Journal democratically spread both the critical Brazilian thinking in Social and Economic Sciences, as well as an European thinking, as we shall see in the invited articles by Luiz Carlos Bresser-Pereira and Jean-François Chanlat in this edition.

Luiz Carlos Bresser-Pereira has been writing for the Journal since its beginnings, with more than 30 articles published over the decades. As he confesses in his article in this special edition, the first article he submitted to RAE when the Journal was launched in 1961, but it was rejected by its then-Editor-in-chief. For those who do not know it, it is worth reading the rejected article: "The rise of the middle-class and middle management in Brazil", which was published in the Journal of Inter-American Studies (1962a), being an essential reading for understanding the role of professional administrators in the country's economic development.

The first article he had published in RAE was in 1962 and deals with the "Economic development and the businessman", in which the author defines what development is and discusses the role of businesspeople in the expansion of the economy. He draws a distinction between the businessperson, the administrator, and the capitalist, and deals with the relationship between businesspeople and the State, as being "two strategic agents of development" (Bresser-Pereira, 1962b, p. 90). Bresser-Pereira's texts on the need for the professionalization of Administration in Brazil were also important. In 1966, before it was regularized, Bresser-Pereira pointed out the importance of the profession, in "The professional administrator and the perspectives of Brazilian society", and defined it thus:

Administration is undoubtedly a profession, provided it is a specialized, paid activity with its own purpose, and it constitutes a source of revenue, par excellence, for those who exercise it. A professional business administrator is an individual, who, without owning a company, makes decisions about its human and material resources, and plans, organizes and controls its operations. He is the man (sic) who performs these specialized functions because of his professional competence, and not because he is the owner of the company, or because he has relationships of kinship or friendship (Bresser-Pereira, 1966, p. 89).

It is impossible in this space to reflect on all the contributions of these thirty or so articles by Bresser-Pereira, a task that historiographical research in Administration in Brazil should revisit. In the article in this edition, "After capitalism, democratic managerialism", Bresser-Pereira (2021, p.1) deals with the decay of the neoliberal model in the United States, presents his classification of the phases of capitalism and his thesis that "capitalism has ceased to produce economic development and human progress". The author suggests that in this new moment " ... managers, or technobureaucrats, have once again become strong and constitute the nucleus of a new coalition of dominant classes". He has an optimistic vision of the future in a post-capitalist world, which he calls a future of "bureaucratic managerialism". The author asks: What is the function of wealth without a social function? This is a fundamental question for the world today, in which new strands in research in Administration, with its focus on the UN's Sustainable Development Goals and the social impact of business schools, are providing some hope. 
Since its origin, RAE has been featuring articles that have a critical approach, known today as Critical Management Studies. The basis of the critical perspective was anchored in French authors - although not only and the history of French thinking in constructing Brazilian academia in Administration is retold by Jean-François Chanlat in his invited article for this special edition. Chanlat writes for RAE and is a frequent speaker at academic congresses in Brazil, especially at the National Meeting of the National Graduate Association (Encontro da Associação Nacional de Pós-Graduação em Administração [EnANPAD]), which is promoted by ANPAD, and his presence is frequent in various business schools throughout the country. As the author recalls in his article, "The influence of French language thought on the Brazilian administrative sciences: A Quebec French look" (Chanlat, 2021), his relationship with Brazilian researcher's dates back to the 1980s, in the figure of Professor Roberto Fachin, one of the creators of ANPAD in 1976 (Fachin, 2006). In the 1990s., Chanlat had contact with two professors from FGV EAESP, Ofélia de Lana Torres and Fernando Prestes Motta, and Professor Tania Fisher from Federal University of Bahia (Universidade Federal da Bahia [UFBA]). Since then, Chanlat's has had a frequent contact with several professors and researchers in the field of Administration in Brazil, when he has visited the country and also welcomed professors and students at Paris-Dauphine. Several of his articles and works have been translated into Portuguese.

In addition to the affective memories that the author had - and still has - of the country, Chanlat writes in this article about the history of French thinking in Brazil, which is not a one-way street, however: while French authors were well accepted in the country, French academia was also open to Brazilian thinkers. The anthropophagic view shows that this exchange is intense and, as the author points out, "an alternative to Anglo-Saxon hegemony" in the field of Administrative Sciences, which had already been criticized by Brazilian authors in Administration, such as Motta and Caldas (1997), Caldas and Wood (1997), Motta, Alcadipani and Bresler (2001), among others. Chanlat stresses that there has been a search for original thinking in Administrative Sciences in Brazil since Guerreiro Ramos, Mauricio Tragtenberg and Fernando Prestes Motta, who distinguished themselves with their critical thinking in Brazilian academia in Administration (Paula, 2015). Chanlat (2021) also highlights contemporary critical authors, such as Alcadipani (2010), Alcadipani and Caldas (2012), Alcadipani and Rosa (2010) and Alcadipani and Faria (2014), among others. His article also explores several French authors who have strongly influenced Brazilian research in ergonomics and psychodynamics at work, in particular C. Dejours in his classic book, "The madness of work", published in Portuguese in 1987. Reading this article by Chanlat is like diving affectionately and joyously into the most recent history of Brazilian academia in Administration.

The next guest article is by the Editor-in-chief of the Brazilian Journal of Public Administration (Revista de Administração Pública [RAP]) and currently the President of ANPAD, Alketa Peci, and her co-author, Lilian Alfaia Monteiro, on the role and impact of academic journals in Administration in Brazil. It is important to highlight that Alketa Peci is the third female president of this important institution in the country, having been preceded by Susana Braga Rodrigues, in 1989-1990, and by Tânia Maria Diederichs Fischer, in 1991-1992, who were both outstanding researchers in the field. For practically three decades, women, active female researchers and founders of the field, have been absent from the presidency of the Association, which is the most important in Administration in the country. The article by Paludi, Helms-Mills and Mills (2014) is very informative with regard to the disappearance of the contribution of women, not only in corporations, but also in Administration academia, because of its "genderized" practices that silence the voices of women in the history of administrative thinking.

In the invited article "Academic journals as agents of the scientific field of Administration", Peci and Monteiro (2021) show that RAE, RAP and RAUSP, which were once practically hegemonic in the field, have started coexisting 
in recent decades alongside more than 300 journals in the field of Administration. This number is a tremendous growth although we still do not know, as pointed out by the authors, "how they are positioned in the scientific field of Administration and how to differentiate between them" (Peci \& Monteiro, 2021). The authors show that the game in the scientific field includes logic, actors and rules of functioning. Within this framework, they undertake a longitudinal analysis of the field of Organizational Studies in Brazil, based on articles collected from RAE, RAP and RAUSP covering the period between the 1960 s and 2014. Supported by this survey, the authors build various categories for the legitimacy strategies of scientific contribution: internal scientific discourse, external scientific discourse, practice discourse, and differentiation discourse. They emphasize that internal scientific discourse and practice discourse "are the main legitimization strategies historically used in the field" (Peci \& Monteiro, 2021, p. 8). In this game in the scientific field, competition also reaches journals that need to distinguish themselves in the rankings, a competitive logic that is imposed by agents such as the Coordination for the Improvement of Higher Education Personnel (Coordenação de Aperfeiçoamento de Pessoal de Nível Superior [CAPES]), the National Council for Scientific and Technological Development (Conselho Nacional de Desenvolvimento Científico e Tecnológico $[C N P q]$, and graduate programs. But the authors stress that the productivism logic does not always contribute towards strengthening the field "in periodicals that are irrelevant from a scientific point of view" (Peci \& Monteiro, 2021, p. 13). This is a fundamental question, which will be taken up again in the next section and that deals with the future challenges of Brazilian periodicals.

In her authorial, profound yet delicate article, Ana Paula Paes de Paula (2021) deals with her personal relationship with the journal: "Thirty years: Life, reading and the written word with RAE". As showed in the article by Chanlat in this edition, Ana Paula's work shows how affections become intertwined with the construction of science. In this article, the author describes her first contact with the Journal while still an undergraduate student in the early 1990 s at the School of Economics, Business and Accounting at the University of São Paulo (Faculdade de Economia, Administração, Contabilidade e Atuária, Universidade de São Paulo [FEA-USP]), later as a student on the Master in Public Administration program at FGV EAESP and, also, during her PhD studies in Social Sciences at the Institute of Philosophy and Human Sciences of the University of Campinas (Instituto de Filosofia e Ciências Humanas, Universidade Estadual de Campinas [IFCH-Unicamp]). Ana Paula highlights that the authors published in RAE, as well as the professors from FGV EAESP, influenced her throughout her academic career. The articles selected by Ana Paula are classics that were published in the Journal: Maurício Tragtenberg (1971), in “Is the general theory of Administration an ideology?"; Thomaz Wood Jr. (1992) in "Fordism, Toyotism and Volvism: The ways of industry in the search for lost time”; Fernando Prestes Motta (1971, 1981, 1992) in: "Social control in organizations", "Disciplinary power in formal organizations" and "Companies and the transmission of ideology". The author also mentions Wood and Caldas (1998) in "Organizational anthropophagy" and Wood (2000) in "Organizations of intensive symbolism." In the 2000s, Paula joined the list of RAE authors, with her article "Tragtenberg and the resistance of the critic: Research and teaching in Administration today" (Paula, 2001), when she also became an associate editor of RAE. This was also the time when Ana Paula took her Post-Doctorate studies at FGV EAESP supervised by Professor Fernando Prestes Motta (and after the professor passed away, by Professor Peter Spink). During this period, together with Professor Thomaz Wood Jr., she coordinated research project into "pop-management” that resulted in several publications. The author's career has been marked, as we can see, by different articles published in RAE, by countless research projects with professors from FGV EAESP, and, of course, by her own fruitful production. Since 2005 as a professor at the Faculty of Economic Sciences of the Federal University of Minas Gerais (Faculdade de Ciências Econômicas, Universidade Federal de Minas Gerais 
[FACE-UFMG]), Ana Paula Paes de Paula stresses that RAE was present as she learned to read and write from the critical perspective that has always marked the Journal.

The invited article that closes this special edition brings a group of women, young members of Brazilian academia in Administration, with their manuscript that points what is a necessary future. Juliana Cristina Teixeira, Josiane Silva de Oliveira, Ana Diniz and Mariana Mazzini Marcondes, young researchers, although recognized already, deal with the subject of "Inclusion and diversity in Management: A manifesta for the future-now". As Bresser-Pereira (2021) points out, what is the value of wealth without a social function? The article by the four authors presents a "manifesta” for Brazilian research into Administration to be plural, inclusive, and representative of the country's geographic and demographic diversity in all its multiple ethnic, racial, age and social dimensions, and to include processes for mending the country's extreme inequality. In addition to their personal experiences, the authors' perspective - two black women and two white women - includes the theoretical contribution of intersectionality, decoloniality and mainstreaming, their clear objective being social transformation. The text provides a brief history of the "management" of diversity, which, although disseminated, was quickly transformed into consumption and empty discourse. It is necessary to highlight that the seminal article in this particular field in Brazil was written by Maria Tereza Leme Fleury and published in RAE in 2000, which indicates, once again, how open the Journal was to emerging and innovative topics in the field of Administration.

Teixeira, Oliveira, Diniz and Marcondes (2021, p.5) emphasize the need to "re-politicize" the debate on diversity and inclusion, to "build a field that is committed to tackling the structural inequality" in Brazilian society. To do so, the authors propose a "transformation agenda" that necessarily includes a change in the logic that operates the inequality in research topics and in the mechanisms that enable this knowledge to be disseminated. The authors also propose that it is necessary to move towards deconstructing the logic that organizes "whiteness" and, consequently, towards what is considered as a scientific product. If the word "diversity" is intended to be inclusive, it is far too general to encompass what is diverse. Naming can be disturbing, but it is part of the change, because language builds reality.

As can be observed in the articles presented in this special isssue, the creative, pioneering, critical and always innovative contributions of RAE helped found the history of Administration in Brazil, but its future challenges are immense, as discussed next.

\section{THE FUTURE CHALLENGES OF RAE (AND BRAZILIAN JOURNALS)}

In its prominent role in the national scenario of producing and disseminating knowledge, $R A E$, faces the challenge of becoming international, not only to expand its capacity to hold a dialogue with the world, but also because of what it represents in terms of pioneering and relevance. The challenge is particularly complex for a journal that helped constructing knowledge in Brazil in the applied and academic fields, and contributed to establishing Administration as a profession and, consequently, to developing the country itself and its worldview in the sociopolitical context (Tonelli \& Zambaldi, 2017). The journal was published predominantly in Portuguese for almost five decades, a period in which it certainly benefited from the freedom it had to favor a research agenda that had relevant objects in the national context. The possibility of building a history and a legacy in Portuguese gave to the Journal autonomy, since the hegemony of English production may adopt a colonial logic that controls the publication and circulation criteria and the definition of what quality is (Rosa \& Alves, 2011). 
CAPES' intensification of the criteria for evaluating journals, with its focus on their impact as calculated by international indexers, encouraged $R A E$ to seek a ranking in these databases in the late $2000 \mathrm{~s}$, resulting in its inclusion in collections such as Journal Citation Reports (JCR) and Scopus. Added to this movement was the orientation coming from the main graduate programs in the area, and from business schools in Brazil, which was to intensify their inclusion in the international context under these same premises. Other Brazilian journals also moved towards internationalization at the same time, while others were founded in the first half of the $2000 \mathrm{~s}$ with the prerogative of publishing all their articles in English. Although this movement made it possible to reach broader audiences, the language barrier is a difficulty for a research community that has not been educated in English, as Farias explained (2017). In a more critical approach, Alcadipani (2017) warned of the risks of the internationalization efforts of our journals in terms of their submission to the Anglo-Saxon aphorism, "publish or perish", with restrictions on the standards of English adopted in communicating as the dominant axes and their topics and approaches, characterizing what he classifies as a global provincialism and an epistemic colonialism.

The products of the efforts of Brazilian Administration academia to internationalize have led to an increase in the production of Brazilian researchers and the presence of our journals in the global context. But they have also somehow forged the standardization of topics and methods in our research, with a greater degree of mimicry in terms of what is published in what we usually classify as top journals. This situation is aggravated, however, by the delay we face in getting to know what is being researched in the centers that have easier access to these periodicals that are classified as top-tier. As Peci and Monteiro (2021) point out, the internationalization of Brazilian production and periodicals in Administration is a new symbolic capital for differentiating journals and articles, in a game that is concentrated on pre-existing references in the fields of study as a legitimizing strategy - the so-called internal scientific discourse (ICD) - with little room for critical assimilation or the adaptation of foreign theories to the national reality as alternatives to directly applying foreign models.

Diniz (2017), who served as RAE's Editor-in-Chief for seven years, considers the internationalization process of Brazilian production and periodicals to be inexorable, and warns of our need not to remain as spectators of the transformations in the world of research, but to develop our own strategies and institutional policies for positioning national journals on the international environment, so as not to be diminished in relation to foreign journals just because they are Brazilian. The indexation of RAE on internationally recognized databases and the increase in the publication of its articles in other languages have led to significant advances in the journal's exposure to Administration academia outside of Brazil, and certainly in its attractiveness for submissions by authors from other countries. Evidence of this is the fact that more than $20 \%$ of all submissions currently come from authors who are affiliated with institutions abroad, with a good distribution in terms of continents. The Journal's initiatives and the results obtained include the availability of our website in three languages, the adoption of a worldwide platform for submissions, international calls for papers, the publication of articles in three languages, greater participation on the editorial board by members from foreign institutions, and the increase in citations on indexed databases and in the proportion of articles written in a foreign language (Tonelli \& Zambaldi, 2017). But some factors, such as the publication of articles predominantly in Portuguese in its history and the scarcity of Brazilian journals that are indexed on international databases - which still represent the largest source of citations of the journal - inhibit the increase of the impact indicators of RAE on the main databases when compared with other journals that are also indexed on them. These factors make it difficult for it to be included in the lists of journals that are valued as publications of excellence in the dominant axes of world academia, such as the Australian Business Deans 
Council (ABDC) and Academic Journal Guide, Association of Business School (AJG/ABS), and are consequently obstacles to the attractiveness of journals in a comparable situation receiving submissions and citations.

The hiring and career development model adopted by the most prominent business schools in the world encourages researchers - especially those at the beginning of their careers - to aim more at journals with greater impact indicators within the dominant criteria, or those that have been included in restricted lists, thereby reinforcing and perpetuating the excluding character of the evaluation processes in such criteria. Researchers are aware of the consequences, but they often react in a resigned manner and show little willingness to promote change, limiting themselves to blaming the system and external entities, as reported by Machado and Bianchetti (2011). These authors warn of the restriction in the topics studied and the consequent limitation of university autonomy, and of researchers becoming alienated from the process that both restricts and drives them.

Maintaining the dynamics described here results in an even greater jettison of journals that have built up a local relevance and developed the ability to dialogue with regional stakeholders. Publications, therefore, often give up their distinctive capabilities at the local level to bring their practices closer to what is done in the publications considered as benchmarks, even though being from competing on equal terms. Consequently, the internationalization process of journals, even bringing advantages of visibility and dialogues with a wider universe and benchmarking opportunities, is also unequal and, in a way, inhibits the potential for building and maintaining the identity of journals that are considered peripheral. A study by Favaretto and Francisco (2017) of RAE's collection until the date of its publication shows the predominance of individual authors in the beginning until a transition to studies with multiple authors (most commonly three) in the most recent publications, considering the benefits and lessons learned from peer collaboration. But the long phase that was characterized by works by only one author was also marked by a vast number of contributions by authors who became the exponents of Brazilian thinking in Administration and related areas. As they became less frequent, they gave way to a kind of abdication of the national identity of the journal by reducing the space of these exponents, even if unintentionally, although most of the production published in the journal is still by Brazilian authors. It is like having a channel for publishing research carried out predominantly by Brazilian authors that is visible and accessible to the outside, but losing part of the distinction of being a channel for spreading the Brazilian thinking.

The standardization trends of practices adopted by journals to attract submissions, evaluate papers, and distribute content are accompanied by the large-scale implementation of unified information and communication systems by academia worldwide, such as the Digital Object Identifier (DOI) for articles and texts in general, the Open Researcher and Contributor ID (ORCID) for researchers, and the Research Organization Registry (ROR) for institutions. These systems have the potential to store and make information widely and quickly available, connect research communities, make searches feasible, and provide complete records on various platforms in the academic environment, thus offering clear benefits. Their potential, however, can be co-opted by current rules that are responsible for the imbalance between journals, or even between research centers with regard to valuing the research that is produced and disseminated. The discussion includes everything from defining which journals deserve global recognition to defining the distribution means that are desirable and possibly deserve more recognition from the academic community.

In addition to the threats to identity issues and the regional relevance of journals in peripheral contexts in the predominant assessment system, there is a contingent of researchers across the globe that is uncomfortable and wants the criteria by which the results of academic research and the researchers themselves are assessed 
to be broadened. This demand can be exemplified by the Declaration on Research Assessment (DORA), which is a comprehensive movement by all fields of knowledge with the participation of various stakeholders, including sponsors, publishers and teaching and research institutions, as well as researchers themselves. The movement is not opposed to integrated systems for storing and disseminating knowledge and its consequent standardization, but it aspires to a wider range of means to be recognized as worthy to disseminate research, both in quantity and in form. Once researchers are recognized and rewarded by their institutions for publishing their research results via channels that are complementary or alternative to cutting-edge periodicals, they will have more freedom to access relevant topics and reach a wider audience, with greater ownership over the dissemination of their research. The potential results for increasing the social impact of research due to the capacity and improved quality of dialogue with different stakeholders in society are promising.

RAE took part in the third Webinar on Management Research Publications of the International Federation of Scholarly Associations of Management (IFSAM) **, which was held recently with the online presence of researchers, editors and teaching and research institutions from different countries. The meeting underlined the desire of the Management research community for formats other than the academic article, such as books, teaching cases, and even audio-visual products and presentations, to be valued and encouraged as research products, in order to give more freedom to researchers in their choice of the means of publication, which can lead to greater reach and a more diverse audience. Although this is a growing demand among researchers, decision makers in educational institutions dealing with the determinants of what is good research performance are concentrating their criteria on the model based on the impact of top journals, which is delaying the growth of journals that have less impact on mainstream indexers, especially considering the time it takes for a publication to obtain an impact index rated as high on these databases. A potential change of course can be fostered, however, by accreditors taking eventual initiatives that are relevant to business schools for also assessing the production of knowledge by its social impact, as EFMD has indicated (EFMD / BSIS, 2020).

The requirement for a wider range of channels for disseminating Management research does not exclude scientific journals, of course, but advocates a lower concentration in journals that are classified as cutting-edge by the dominant criteria, and greater appreciation of niche journals, which are important for specific groups that produce and consume research with some degree of specificity, albeit endowed with relevance for different stakeholders. Even though journals with a historical regional impact may be generalists, such as RAE is, they fit in this group and would have more recognition by focusing on issues that are relevant to the environment in which they operate, such as the challenges faced by emerging nations and specific cultural aspects of Administration that concern objects of global interest because of the particularities and wealth of their contexts. The result could be a reduction in mimicry of the practices adopted by leading journals as far as it concerns the selection of themes and the prioritization of specific methods in assessment processes, giving them a more genuine relevance on the international environment, less anchored in the trends of more hegemonic publications that are a reference globally.

The IFSAM webinar also revealed that the number of article submissions around the world has increased in journals generally, as has happened with RAE, and that topics involving issues such as gender equality and social responsibility have been recurrent and growing in submissions to journals in the area. This may be evidence that researchers, everywhere, are committed to the social impacts of their research, like the UN's Sustainable Development Goals (2021), for example. This is something that may have intensified because of the delicate moment we are experiencing worldwide in the economic and social spheres, which have been strongly impacted by the 
pandemic. In this sense, research results need to be divulged urgently to a society that is interested and affected by the study objects of the Administration field, especially with regard to reaching those who may be agents for introducing relevant research results, known as the management practitioners in different types of organizations.

The super-specialized format for producing and writing the research that is published in journals is an old challenge in academia and it has been intensified by the emphasis on theoretical and methodological rigor and forms of communication. The problem is worldwide and has grown in Brazil with the adoption of rules and practices that have been instituted and strongly encouraged by research regulatory and incentive bodies since the end of the 1990 s (Bertero, 2006c). The way of doing and communicating research tends to be restricted to academic researchers, as is the consequent interpretation of its results. RAE's own history as a journal and its transition at the end of the 2000 s to a periodical that is more aligned with the globally recognized practices of academic publication is evidence of this (Mascarenhas, Zambaldi, \& Moraes, 2011). As an illustration, a text mining analysis of the complete RAE-eletrônica collection from 2002 to 2010 carried out by Francisco (2011) shows that in this decade of transition and acceleration towards adopting the most popular practices of international publications, the main references cited in the articles came not only from RAE itself and from ANPAD meetings, but from international periodicals. The authors who published the most in the period were also affiliated with graduate programs that had the best evaluation from CAPES.

A pertinent and recurring question is whether periodicals should become super-specialized means of communication and restricted to a group of academic researchers - if indeed they are not already - and whether research should be delivered in other formats and media, such as books, mass circulation publications, and summarized audio-visual and digital content. Each piece of research would have to have a version specifically for publication in scientific journals, sealing its rigor and quality, and at least one other version aimed at practitioners and society in general. This alternative is debatable in terms of volume and feasibility, and even of potential results, but it certainly is of interest to scientific journals that want to be recognized beyond academia. An example is the fact that publishers allow authors to make available succinct presentations that are more palatable for practitioners, or even graphic representations of their articles on their communication platforms. It is not impossible that in the future such versions may even have to accompany publication in journals. The results in terms of impact on practice, however, are still unknown.

It is a fact, however, that researchers in Administration deal with real problems of organizations and work diligently, but publish their findings in media that are seldom visited by practitioners. One way of addressing this issue would be to include practitioners in research initiatives and execution, in co-creation processes, so that they are not addressed only as providers of access to the field, or as sources of information. They could make contributions to what is researched and how it is done because they are involved with the process (Mascarenhas et al., 2011). Perhaps, in this manner, they may recognize the value of research in a more natural way and make more intense and effective use of its products. This alternative may be a means of alignment with business schools' initiatives to offer research degrees with a professional emphasis that target management practitioners. The presence of these professional programs is increasing in recognized teaching and research centers, including in Brazil, which can be seen from the proliferation of professional Master's and even DBA programs.

There are many challenges to the future of journals such as RAE and their surrounding communities, and these challenges are are not simple. RAE has a history of local relevance, but face competitive disadvantages in terms of international insertion given the predominant global parameters of research assessment and its 
consequent incentives for researchers. Dealing with such challenges requires investment and collaborative work due to opportunities that are also opening up. In this context, it is difficult for a periodical supported by a business school to be competitive in a market in which professional publishers prevail. This situation - it should be emphasized - applies to most journals in the area in Brazil, because they are usually attached to and supported by graduate programs (Alencar, 2017). Publishers have professional teams, gains of scale, prestige and unique competences. Furthermore, they benefit from a business model by which authors produce content with rigor and serve as assessors to guarantee the quality of what their peers produce. But they do not benefit monetarily from the system because they are not remunerated or able to access the content without having to pay for it (or their institutions have to pay). This is uncomfortable for many researchers, although publishers are aware of this and are already joining discussions and initiatives that aim to provide a more equitable relationship in terms of contributions and rewards. One of these initiatives is the increase in the supply of free, open access, research content (Diniz, 2017), which, however, often comes up with questions regarding quality aspects and burdens authors or institutions with publication costs (Alencar, 2017). In this scenario, periodicals that do not have the broad professional structure of a publishing group will face increasing difficulties in maintaining themselves in the medium and long term, as will researchers in institutions and environments in which monetary resources are not abundant.

\section{TO WRAP THINGS UP}

RAE has been a solitary star throughout its trajectory, but the long half-life of its articles has two facets: on one side, it shows the importance of the classic articles and authors that have been repeatedly cited, but on the other side, these citations are not considered when international indexers calculate their impact factor. This is the price paid for this decades-long trajectory. As we have shown in the previous sections, RAE, like other Brazilian journals, suffers from a lack of identity and the difficulty of being further included in the international scientific debate. Another aspect that should be highlighted is that, whereas in its trajectory RAE had solitary authors, the future of research increasingly calls for group efforts, as represented in this edition by a group of black and white women in order to highlight the often forgotten demographic and racial representativeness in Brazil. We can celebrate the fact that RAE has become more collaborative during its trajectory.

By opening up to the world more, and given the speed of its internationalization process, RAE and the Brazilian production in the area as a whole have come to be seen by a larger universe, which has certainly been facilitated by the adopted model of open access to its entire collection, in conjunction with the indexing and improvement of communication processes and being published in other languages. Even though as a result it has given up part of its identity as a space for constructing and disseminating a national thinking in Administration, it moves forward without relinquishing its vocation for social impact and the contribution it makes to several demands, such as the reduction of different inequalities, environmental and social sustainability, social inclusion, and social and economic development. Different researchers and editors in the world's academia are increasingly addressing these topics, whether in hegemonic axes or not. As a result, there is an opportunity for RAE and other comparable publications to assume responsibility for partly leading these transformations in the context of academic publication. The consequences of the pandemic that we are experiencing, many of which are still 
unknown, legitimize and encourage this path and are opportunities for the journal to strengthen its position as it paves a way to a more inclusive and conscientious world in the field of Management.

The path is not a lonely one, nor should it be, since it requires dialogue with different agents, such as publishers, sponsors, teaching and research institutions, the community of researchers, indexers, regulatory bodies, accreditors and other journals. Among researchers, the inclusion of management practitioners as co-creators and the legitimizers of the research and publication process is important for ensuring and expanding the relevance of articles and their integration with the growing number of professional research degree programs. With regard to the support of educational institutions, it will only be possible to envision a path that has a greater social impact on publishing in Administration if these institutions and their graduate programs embrace a greater diversity of periodicals and media that commit to this impact. This also depends on the support of Brazilian regulatory research agencies. If not, the efforts to unify and standardize information about research, institutions and authors will be biased and will run the risk of perpetuating the inequality of conditions between those publications that are global leaders and those that follow them. Reducing these inequalities can be seen as a goal for RAE and other Brazilian periodicals that can take advantage of favorable winds, such as the UN's Sustainable Development Goals, the DORA movement, and the potential of accreditation associations for assessing the social impact of institutions and their programs. But relying only on these favorable winds to do the job would be an illusion, so a lot of work lies ahead.

Over the years, RAE has been a pioneer, capable of reinventing itself and proposing innovations. The invited articles in this special edition show its strength and its inestimable role in building Brazilian academia in Business Administration. May the journal have a long life and celebrate its 120 years in the not-so-distant future.

\section{NOTES FROM THE AUTHORS}

* We express our deep condolences for the many losses suffered and the damage done, not only in the academic community in Administration, but also in the country as a whole.

** Our thanks to Xavier Castañer, from IFSAM, and Alketa Peci, from ANPAD for the opportunity.

\section{REFERENCES}

Alcadipani, R. (2010). Critical international management and international critical management: Perspectives from Latin America. Critical Perspectives on International Business, 6(2/3). doi: 10.1108/cpoib.2010.29006baa.001

Alcadipani, R. (2017). Periódicos brasileiros em inglês: A mímica do publish or perish "global". RAE-Revista de Administração de Empresas, 57(4), 405-411. doi: 10.1590/s0034-759020170410

Alcadipani, R., \& Bertero, C. O. (2012). Guerra Fria e ensino do management no Brasil: 0 caso da FGV-EAESP. RAE-Revista de Administração de Empresas, 52(3), 284-299. doi: 10.1590/ So034-75902012000300002

Alcadipani, R., \& Caldas, M. P. (2012). Americanizing Brazilian management. Critical Perspectives On International Business, 8(1), 37-55. doi: 10.1108/17422041211197558
Alcadipani, R., \& Faria, A. (2014). Fighting Latin American marginality in "international" business". Critical Perspectives on International Business, 10(1/2), 107-117. doi: 10.1108/ cpoib-11-2013-0047

Alcadipani, R., \& Rosa, A. R. (2010). The researcher as the other: A postcolonial reading of the Brazilian "Borat". RAE-Revista de Administração de Empresas, 50(4), 371-382. 10.1590/So03475902010000400003

Bertero, C. O. (1968). Algumas observações sobre a obra de G. Elton Mayo. RAE-Revista de Administração de Empresas, 8(27), 73-95. doi: 10.1590/S0034-75901968000200003

Bertero, C. O. (2006a). Editorial. RAE-Revista de Administração de Empresas, 46(2), 5. doi:10.1590/So034-75902006000200001 
Bertero, C. O. (2006b). A RAE nos seus 45 anos. RAE-Revista de Administração de Empresas, 46(2), 114-117. doi: 10.1590/ So034-75902006000200008

Bertero, C. O. (2006c). Ensino e pesquisa em administração. São Paulo, SP: Thomson Learning.

Bertero, C. O. (2011). Meio século de RAE. RAE-Revista de Administração de Empresas, 51(3), 224-226. doi: 10.1590/ So034-75902011000300002

Bertero, C. O. (2021). Sessenta anos de RAE: Um itinerário de críticas, resistências e reinvenções. RAE-Revista de Administração de Empresas, 61(3), eoooo-0011. doi: 10.1590/ So034-759020210303

Bertero, C. O., \& Keinert, T. M. M. (1994). A evolução da análise organizacional no Brasil (1961-93). RAE-Revista de Administração de Empresas, 34(3), 81-90. doi: 10.1590/ So034-75901994000300007

Bertero, C. O., Vasconcelos, F. C. D., Binder, M. P., \& Wood, T., Jr. (2013). Produção científica brasileira em administração na década de 2000. RAE-Revista de Administração de Empresas, 53(1), 12-20. doi: 10.1590/So034-75902013000100002

Bresser-Pereira, L. C. (1962a). The rise of middle-class and middle management in Brazil. Journal of Inter-American Studies, 4(3), 313-326. doi: 10.2307/164949

Bresser-Pereira, L. C. (1962b). Desenvolvimento econômico e o empresário. RAE-Revista de Administração de Empresas, 2(4), 79-91. Retrieved from http://bibliotecadigital.fgv.br/ojs/ index.php/rae/article/view/38445

Bresser-Pereira, L. C. (1966). O administrador profissional e as perspectivas da sociedade brasileira. RAE-Revista de Administração de Empresas, 6(20), 89-110. doi: 10.1590/ So034-75901966000300004

Bresser-Pereira, L. C. (2021). Depois do capitalismo, o gerencialismo democrático. RAE-Revista de Administração de Empresas, 61(3), e0000-0012. doi: 10.1590/S0034 759020210304

Caldas, M. P., \& Wood, T., Jr. (1997). Identidade organizacional. RAE-Revista de Administração de Empresas, 37(1), 6-17. doi: 10.1590/So034-75901997000100002

Caldas, M. P., \& Wood, T., Jr. (2000). Fads and fashions in management: The case of ERP. RAE-Revista de Administração de Empresas, 40(3), 8-17. doi: 10.1590/So03475902000000300002

Chanlat, J.-F. (2021). Influência de pensamento de língua francesa na academia brasileira de administração: Um olhar francoquebequense. RAE-Revista de Administração de Empresas, 61(3), eoooo-0013. doi: 10.1590/So034-759020210305

Diniz, E. H. (2017). Periódicos brasileiros da área de administração no contexto de internacionalização da produção científica. RAE-Revista de Administração de Empresas, 57(4), 357-364. doi: 10.1590/s0034-759020170406

EFMD Global services/ Business School Impact System (2020). Business School Impact System/Assessment criteria guide. Retrieved from efmdglobal.org/bsis - fnege.org/nos-programmes/bsis
Fachin, R. C. (2006). Construindo uma associação científica: Trinta anos de ANPAD - memórias, registros, desafios. Porto Alegre, RS: ANPAD.

Farias, S. A. D. (2017). Internacionalização dos periódicos brasileiros. RAE-Revista de Administração de Empresas, 57(4), 401-404. doi: 10.1590/s0034-759020170409

Favaretto, J. E. R., \& Francisco, E. D. R. (2017). Exploração do acervo da RAE-Revista de Administração de Empresas (de 1961 a 2016) à luz da bibliometria, text mining, rede social e geoanálise. RAE-Revista de Administração de Empresas, 57(4), 365-39o. doi: 10.159o/s0034-759020170407

Francisco, E. D. R. (2011). RAE-eletrônica: Exploração do acervo à luz da bibliometria, geoanálise e redes sociais. RAE-Revista de Administração de Empresas, 51(3), 280-306. doi: 10.1590/ So034-75902011000300008

Machado, A. M. N., \& Bianchetti, L. (2011). (Des)fetichização do produtivismo acadêmico: Desafios para o trabalhadorpesquisador. RAE-Revista de Administração de Empresas, 51(3), 244-254. doi: 10.1590/S0034-75902011000300005

Mascarenhas, A. O., Zambaldi, F., \& Moraes, E. A. D. (2011). Rigor, relevância e desafios da academia em administração: Tensões entre pesquisa e formação profissional. RAE-Revista de Administração de Empresas, 51(3), 265-279. doi: 10.159o/ So034-75902011000300007

Motta, F. C. P. (1971). A teoria geral dos sistemas na teoria das organizações. RAE-Revista de Administração de Empresas, 11(1), 17-33. doi: 10.1590/So034-75901971000100003

Motta, F. C. P. (1981). O poder disciplinar nas organizações formais. RAE-Revista de Administração de Empresas, 21(4), 33-41. doi: 10.1590/S0034-75901981000400003

Motta, F. C. P. (1992). As empresas e a transmissão da ideologia. RAE-Revista de Administração de Empresas, 32(5), 38-47. doi: /10.1590/So034-75901984000300004

MOTTA, F. P. (1979). Controle social nas organizações. RAERevista de Administração de Empresas, 19(3), 11-25. doi: 10.1590/So034-75901979000300002

MOTTA, F. P., \& CALDAS, M. (1997). Cultura organizacional e cultura brasileira. São Paulo: Atlas, 1997.

Motta, F. C. P., Alcadipani, R., \& Bresler, R. B. (2001). A valorização do estrangeiro como segregação nas organizações. Revista de Administração Contemporânea, 5(SPE), 59-79. doi: 10.1590/ S1415-65552001000500004

Organização das Nações Unidas Brasil. (2021, março). Sobre o nosso trabalho para alcançar os Objetivos de Desenvolvimento Sustentável no Brasil. Retrieved from https://brasil.un.org/ $\mathrm{pt}-\mathrm{br} / \mathrm{sdgs}$

Paludi, M., Helms-Mills, J., \& Mills, A. J. (2014). Disturbing thoughts and gendered practices: A discursive review of feminist organizational analysis. In S. Kumra, R. Simpson, \& R. J. Burke, The Oxford handbook of gender in organizations. Oxford: Oxford Press.

Paula, A. P. P. de. (2001). Tratenberg e a resistência crítica: Pesquisa e ensino em administração hoje. RAE-Revista de Administração de Empresas, 41(3), 77-81. doi: 10.1590/ So034-75902001000300010 
Paula, A. P. P. de. (2015). Estudos organizacionais críticos e pen sadores nacionais. Cadernos EBAPE.BR, 13(3), 410-413. Retrieved from http://bibliotecadigital.fgv.br/ojs/index. php/ cadernosebape/article/view/49070

Paula, A. P. P. de. (2021). Trintena: Uma trajetória de vida, leitura e escrita com a RAE. RAE-Revista de Administração de Empresas, 61(3), eoooo-0015. doi: 10.1590/So034-759020210307

Peci, A., \& Monteiro, L. A. (2021). Revistas acadêmicas como agentes do campo científico de administração. RAE-Revista de Administração de Empresas, 61(3), eoooo-0014. doi: 10.1590/So034-759020210307

Rosa, A. R., \& Alves, M. A. (2011). Pode o conhecimento em gestão e organização falar português? RAE-Revista de Administração de Empresas, 51(3), 255-264. doi: 10.1590/ So034-75902011000300006

Teixeira, J. C., Oliveira, J. S, Diniz, A., \& Marcondes, M. M. (2021). Inclusão e diversidade na administração: Manifesta para o futuro-presente. RAE-Revista de Administração de Empresas, 61(3), eoooo-0016. doi: 10.1590/So034-759020210308

Tonelli, M. J. (2017) The foundation of the academic field in business and administration in Brazil: The case of RAUSP. RAUSP-Management Journal, 52(4), 359-362. doi: 10.1016/j. rausp.2017.08.001
Tonelli, M. J. (2018). Revistas científicas sobre administración: El papel histórico de la RAE-Revista de Administração de Empresas (RAE) en la construcción del campo académico de la administración en Brasil. Cadernos EBAPE. BR, 16(spe), 509-515. doi: 10.1590/1679-395173941

Tonelli, M. J. \& Zambaldi, F. (2017). Editorial. RAE-Revista de Administração de Empresas, 57(4), 1-2. doi: 10.1590/s0034759020170401

Tragtenberg, M. (1971). A teoria geral da administração é uma ideologia? RAE-Revista de Administração de Empresas, 11(4), 7-21. doi: 10.1590/So034-75901971000400001

Valente, R., \& Serafim, M. C. (2006).RAE 45 anos: recortes de sua história. RAE-Revista de Administração de Empresas, 46(2), 104-111. doi: 10.1590/So034-75902006000200007

Wood, T., Jr. (1992). Fordismo, toyotismo e volvismo: Os caminhos da indústria em busca do tempo perdido. RAE-Revista de Administração de Empresas, 32(4), 6-18. doi: 10.1590/So03475901992000400002

Wood, T., Jr. (2000). Organizações de simbolismo intensivo. RAE-Revista de Administração de Empresas, 40(1), 20-28. doi: $10.1590 /$ So034-75902000000100003

Wood, T., Jr., \& Caldas, M. P. (1998). Antropofagia organizacional. RAE-Revista de Administração de Empresas, 38(4), 6-17. doi: 10.1590/So034-75901998000400002

\section{AUTHORS' CONTRIBUTIONS}

The authors declare that participated in all stages of the development of the manuscript. From the conceptualization and theoretical-methodological approach, the theoretical review (literature survey), the writing, and final revision of the manuscript. 